\title{
José MEDINA, The Epistemology of Resistance
}

Oxford, Oxford University Press, 2012, 352 pages

\section{Roberto Frega}

\section{(2) OpenEdition \\ 1 Journals}

\section{Electronic version}

URL: http://journals.openedition.org/ejpap/678

DOI: $10.4000 /$ ejpap. 678

ISSN: 2036-4091

\section{Publisher}

Associazione Pragma

\section{Electronic reference}

Roberto Frega, "José MEDINA, The Epistemology of Resistance », European Journal of Pragmatism and American Philosophy [Online], V-1 | 2013, Online since 16 July 2013, connection on 23 September 2020. URL : http://journals.openedition.org/ejpap/678 ; DOI : https://doi.org/10.4000/ejpap.678

This text was automatically generated on 23 September 2020.

\section{(c) $\Theta \Theta \Theta$}

Author retains copyright and grants the European Journal of Pragmatism and American Philosophy right of first publication with the work simultaneously licensed under a Creative Commons AttributionNonCommercial-NoDerivatives 4.0 International License. 


\title{
José MEDINA, The Epistemology of Resistance
}

Oxford, Oxford University Press, 2012, 352 pages

\author{
Roberto Frega
}

\section{REFERENCES}

José Medina, The Epistemology of Resistance, Oxford: Oxford University Press, 2012, 352 pages

1 The new book from José Medina offers an inspiring exploration of how the recent discussions of "epistemic ignorance" can be put to work to unveil and denounce new forms of oppression. José Medina accomplish this task by combining four different tradition: American pragmatism, Wittgenstein, Foucault, and feminist and race studies. This original blend of different traditions gives the book its distinctive flavor and accounts for its originality.

One way to read this text is to see it as a book in political philosophy rooted in the tradition of nonideal theory, and therefore committed to a wide concern for social issues. This concern is formulated in an explicitly epistemic tonality. Medina tries indeed to work out some of the epistemological assumptions that according to him underlie and perpetuate forms of social oppression. Put in a nutshell, the idea is to unfold the epistemic resources and obstacles involved in the normative dynamics by which oppression is produced, reproduced, contested and finally overcome. To reach his goal, Medina relies on the notion of epistemic injustice, recently introduced in the philosophical debate by Miranda Fricker, to define his own concept of epistemic resistance. Starting from the assumption that there exists distinctly epistemic kinds of injustice, and that oppression has a distinctive epistemic dimension, Medina defends the idea that we need to explore the typical epistemic resources on which social actors can rely to contrast the forms of social oppression affecting them. 
3 By "epistemic resistance," the author means "the use of our epistemic resources and abilities to undermine and change oppressive normative structures and the complacent cognitive-affective functioning that sustains those structures" (3). Epistemic resistance is clearly a political act, as it is addressed against injustices that are embedded in social relations. This resistance model is introduced with the explicit aim of overcoming the standard dualism between consensus models and agonistic models by relying on what Medina takes to be a broader understanding of democratic life as being based on communicative engagements.

4 The political meaning of resistance developed by this book derives also from a second source, which is a contestatory conception of democracy. Relying on works from Elizabeth Anderson and Iris M. Young, Medina assumes a model of democracy based on the notion of resistance rather than on the notion of consensus. His main idea is that "in democratic societies, given their commitment to free and equal epistemic participation, there is a prima facie interest and obligation to detect and correct the systematic disparities in the epistemic agency that different members of society can enjoy and the inequalities associated with them" (4). The obligation to combat epistemic injustices derives therefore from the previous acceptance of an epistemic justification of democracy. Contestation is an essential feature of democracy, and the epistemic resistance refers to the epistemic and political mechanisms that sustain it.

5 Here we should see the first element of interest for pragmatists, since Medina, following Anderson, considers Dewey's experimentalist account of the epistemic powers of democracy as the best instantiation of the resistance model, given - they both contend - the central role Dewey assigns to contestation and dissent as central virtues of democracy. According to both scholars, compared to other models, Dewey's is "the only model in which dissent is epistemically productive." The importance of epistemic resistance is therefore to be seen within the framework of an epistemic justification of democracy: democracy is the only regime that renders conflict epistemically productive. Thanks to this, democracy can assign a positive value to diversity, interaction, and dynamism: "it is because we want to exploit the benefits of productive dissent that we need to recognize and take advantage of the heterogeneous situated knowledge of diverse agents."

6 Starting from these broad assumptions Medina defines the two normative requirements that inform his understanding of democracy and that pave the way for his analysis and critique of epistemic oppression and resistance. The first requirement is the Expressibility Requirement: it "demands that the different groups that a social body can contain have the opportunity to coalesce in a public with expressive capacities, so that they can articulate their shared experiences and perspectives." Expressibility requires that spaces and opportunities for group formation be provided. The second requirement is the Responsiveness Requirement, according to which "the social and epistemic conditions of communication and interaction be such that the expressions of a public have the proper uptake by other publics and by society as a whole" (9). The study of epistemic injustices is the study of how these minimum requirement can fail, and of the negative effects on democratic life produced by these failures.

7 Medina's focus is restricted to two specific forms of oppression which are racial and gender inequality, to which Medina assigns a specific epistemic significance. Indeed, "in contexts of sexual and racial oppression there are cognitive-affective deficits that amount to specific forms of epistemic insensitivity: the inability to listen and to learn 
from others, the inability to call into question one's perspective and to process epistemic friction exerted from significantly different perspectives" (17-8). This lack of knowledge for Medina is at the same time a lack of self-knowledge (of who I am as a situated agent) and a lack of social knowledge (of social inequalities, and situations of asymmetry and oppression). Here we can grasp the political relevance of an analysis of social oppression and inequality developed in terms of epistemic conditions.

8 The book articulates these general theoretical assumptions in details. It proceeds first to define the basic epistemological terminology adopted (chs. 1 and 2). It then puts these concepts to use in exploring the different epistemic dimensions of social experience, providing specific emphasis to the moral and political implications of the epistemic dimensions of silence and ignorance (chs. 3 and 4). It then proceeds to work out a theoretical model of epistemic resistance to counter present forms of social oppression (chs. 5 and 6). One of the central thesis that the book defends is that of a reciprocal co-implication of the epistemic and the political. This thesis has two main corollaries. The first is the attribution of moral and political meaning to epistemic states, as it is the case in the claim that agent bear moral responsibility for their ignorance. The second corollary is the symmetrical emphasis on the epistemic dimension of morality and politics, exemplified by the idea that morality and politics are rooted in specific epistemic virtues, among which Medina emphasized "metalucidity."

9 From the epistemic perspective adopted by Medina, "inequality is the enemy of knowledge." As a consequence, social injustice and epistemic injustice are two faces of the same coin. In a nutshell, the argument claims that oppression produces inequality; inequality produces epistemic injustice, and epistemic injustice in turn impoverishes our democratic life. According to Medina, while oppression is clearly asymmetrical, its epistemic consequences affect both oppressors and oppressed, albeit not in the same way. This point is strategic in Medina's argumentation, because one of the conclusions he wants to bring home is that epistemic oppression harms oppressors as well, producing damages that according to studies in feminism and race theory can be conceptualized as specific forms of ignorance and epistemic vices. Among the vices that privileged groups are likely to contract Medina lists epistemic arrogance, epistemic laziness, and close-mindedness. These are epistemic vices because "they affect one's capacity to learn from others and from the facts; they inhibit the capacity of selfcorrection and of being open to corrections from others" (31). Symmetrically, Medina identifies three epistemic virtues that tend to be associated with the social experience produced by oppression: humility, curiosity/diligence, and open-mindedness. Medina is clear in emphasizing that virtues and vices are not attributes of social groups but correlates of experiences. The upshot of this analysis is that marginalized people may have privileged access to social knowledge as they tend to develop a subversive lucidity (defined as the sum of the three epistemic virtues) out of which they "are likely to detect and overcome blind spots and to develop new forms of lucidity that can enrich social cognition" (45). People belonging to oppressed groups are likely to gain "metalucidity," a "capacity to see the limitations of dominant ways of seeing. [...] This metalucidity has a critical and subversive potential: it provides insights into the functioning of perspectives that makes it possible to redraw our cognitive maps, to redescribe our experiences, and to reconceptualize our ways of relating to others" (47). 

on which Medina relies to invoke resistance as a moral and political virtue. Resistance has a positive epistemic function because it provides friction, and friction is essential to assure the alignment between our beliefs and attitudes and reality. Our capacity to resist received social schemes, ways of seeing and perceiving, and consolidated habits is therefore transformed into a propeller of social change. And because in the last resort each of us is responsible for her way of knowing, this claim provides the starting point of the whole normative argument Medina develops to defend the idea that agents should be considered morally responsibility for their beliefs and epistemic virtues, which in turn implies the idea of a moral and political culpability for ignorance.

To explain Medina's strategy we need to introduce a further specification: relying on authors like Shannon Sullivan and Charles Mills, Medina emphasizes the tacit and often unconscious dimension of virtues. To this extent he introduces the concept of "active ignorance" precisely to identify a form of ignorance that protects itself through psychological and socio-political mechanisms of defense. He equally explores how social imaginaries contribute to the preservation of social ignorance by determining the space of what is sayable and acceptable and what is not. What is socially thinkable affects the epistemic credibility of a subject as it tends to pre-define the discursive space in which he will orient himself. Another concept he introduces to describe the epistemic dimension of social oppression is that of "meta-blindness." Meta-blindness is the blindness to one's own blindness, which therefore concurs to reinforce blindness. The distinction between blindness and metablindness serves specific critical purposes such as the critique of race-blind politics.

distinction between blindness and meta-blindness serves also to ground the detailed analysis of silencing as a social process through which oppression is created and maintained. Following Miranda Frickers' analysis of hermeneutical justice, that he develops and expands considerably, Medina insists on the social dimension of this specific form of epistemic ignorance. Medina develops a pluralist approach to epistemic injustice according to which a society is fragmented into interpretative communities, so that injustices affect individuals according to the community they belong to. "Social silences and hermeneutical gaps are incorrectly described if they are uniformly predicated on an entire social context, instead of being predicated on particular ways of inhabiting that context by particular people in relation to particular others" (90). The long discussion of Frickers' thesis is precisely aimed at providing an analysis of epistemic injustices that takes social circumstances into account. This is an important and original contribution Medina brings to the debate about the nature of epistemic injustices.

It is indeed because he can show that epistemic injustices have a social basis that Medina can derive normative conclusions from his analysis. In particular, by relying on analyses developed by Iris M. Young and Larry May, Medina introduces the idea of a shared responsibilities for our epistemic weaknesses: "communities share a collective responsibility to do everything they can to facilitate everyone's ability to participate in meaning-making and meaning-expressing practices" (109). Duties are proportional to the degree of marginalization of the groups we interact with, so that responsibility will have to be determined relationally and positionally: "whether individuals and groups live up to their hermeneutical responsibilities has to be assessed by taking into account 
the forms of mutual positionality, relationality, and responsiveness (or lack thereof) that these subjects and groups display with respect to one another."

The normative requirement that Medina establishes through his analysis of the social causes of epistemic oppression is expressed through the thesis of the "cognitive minimums" that opens ch. four. The cognitive minimum states that "responsible agency requires that one be minimally knowledgeable about one's mind and one's life, about the social world and the particular others with whom one interacts, and about the empirical realities one encounters" (127). If one then admits that self-knowledge can be attained only in the absence of systematic distortions and of cultivated forms of blindness and ignorance, the normative argument in support of affirmative actions for removing epistemic ignorance follows. Medina's idea is that epistemic ignorance puts agents in states of reduced autonomy. This holds for oppressed as well as for oppressors. "Systematic injustices produce irresponsible agents, for they tend to lack knowledge of themselves, of others, and of the world" (131).

Given the connection between knowledge and responsibility, Medina explores at great length the thesis of an obligation to know considered as the reverse of a moral culpability of ignorance. Medina contends that there are specific forms of ignorance which are not excusable, and therefore enables to identify precise forms of responsibilities: of agents, of educators, of communities. Given Medina's contextualism, the extent of an agent's obligation to know is limited by the social and cultural horizon of his experience. Medina identifies three criteria that may be used to prioritize our obligations to know on which to rely to order our obligations according to a criteria of relevance. The three criteria are: (a) a maxim to prioritize others according to proximity, taking as a guideline the idea of sharing of resources and/or social spaces, of being co-participant in social domains; (b) a maxim of openness and vigilance in always trying to find out more about others; and (c) a maxim of shared responsibility between community and individuals in determining relevance. These maxims are proposed as guidelines that should facilitate individuals and communities in checking the appropriateness of their perceptions.

Chapters five and six present the most constructive part of the argument, where Medina articulates his political vision of epistemic resistance as a sum of strategies aimed at contrasting and overcoming forms of social oppression. In chapter five Medina introduces the normative concept of "meta-lucidity," identifying what he describes as the "epistemic heroes" whose everyday struggles contribute to restore epistemic justice. This is the chapter where Medina engages most intensely with the idea of an emancipatory role of the oppressed based on the epistemic virtues that they have developed to survive to the manifold forms of social and epistemic oppression they undergo. In particular, Medina relies on post-colonial and feminist thought to emphasize the epistemic distortion that is produced when racialized images of the oppressed circulate in the social body: racial others are no more perceived in their own identity but as the effect of a boomerang perception (Spelman): the white perceives the racialized other only through the image he himself has created, projected onto the other and received back. Epistemically, the experience of invisibility shows to agents affected by it that social perception is fallible: because they see things others do not, they become aware that there is always more to be seen than what is seen: they can therefore develop the attitude of "being always on the lookout for more, forever more, which is based on the experience that there can be more than what is seen" (192). Meta 
lucidity is an indispensable attitude for those that live in conditions of oppression if they want to maintain epistemic responsibility. The oppressed are epistemically favored because their experience produces the clash of different perspectives, what W. E. B. du Bois called "double consciousness." Double consciousness can bring with it the capacity to shift between visions and therefore acquire critical capacity. But it can also produce cognitive dissonance. Here Medina relies on Linda Alcoff's project of a transformative and reconstructive approach to white identity: whites must learn to accept the socio-historic genesis of their biased identity in order to transform it. The central point is that discrimination and oppression are rooted in deep habits that are difficult to undo. As a consequence, long processes of learning and transformation are required. "We need to explore ways in which subjects can reconstruct their perspectives and learn to inhabit them in new ways, so that they can reconstitute their positionality and relationality in a racialized social environment" (220). The overall argument, to which we are already familiar, is that transformation requires friction and resistance in order to disrupt consolidated habits. In its turn, friction produces awareness, which in its turn favors the transformation of habits. As identities are socially shaped, processes of personal transformation are essentially social.

To make sense of the intrinsically social dimension of these processes Medina relies on John Dewey's theory of the publics and on G. H. Mead's theory of the generalized other: following Dewey Medina remarks that "a social network becomes an organized social group or movement [...] when and because its members engage in communication with one another and make their problems interests, and goals explicit" (226). Mead is invoked shortly after to defend a position of epistemic perspectivism: "the epistemic friction produced by the interaction of heterogeneous standpoints can yield a critical awareness of multiple ways of perceiving and can point in the direction of change, of the melioration of our perceptual attitudes and habits." Both references have to be understood with reference to the central role pragmatist epistemology assigns to friction as a distinctive feature of human experience. For Medina as well as for the pragmatists friction is the starting point for changing habits. Friction can both disrupt existing habits and foster the formation of new ones.

Still from pragmatism Medina draws the idea that social transformation requires a transformation of social imagination. Imagination is crucial because it engages will and is therefore closer to action than reason. In addition imagination is positional: it concerns our relation in the world and to others. Thirdly, following Dewey Medina emphasizes the experimental and creative role of imagination: "in the dramatic imagination we explore our inhabitation of possible scenarios that, insofar as they concern forms of social positionality and relationality, call for moral and political reactions" (256). Hence the idea that the interaction between social imageries may favor processes of imaginative resistance. In fact, "imaginations with different moral and political sensibilities can function as epistemic counterpoints to each other." Therefore, "by comparing and contrasting their imaginative resistances, people can become sensitive to other ways of imagining and inhabiting worlds of possible experiences" (256).

19 Imagination is favored by Medina also because it operates at the interface of individual and society: whereas it is always individuals that imagine, they do it by relying on materials that are forged by social relations. A further element Medina draws from pragmatism to develop his theory of resistant imaginations is James' pluralism: 
imagination enables us to see the meaningfulness of other's lives. In this sense, imaginative pragmatism is the habits of always seeing an alternative, of seeing things in perspectives. Medina relies on James as against what he presents as a Peircean and Meadian conception of consensus pluralism to defend a more agonistic view of pluralism in which conflict is at the same time productive and never solved. Pragmatically, he sees agreement as a temporary and instrumental achievement: in social life as well as in political practice unification is searched only for matters of action, not truth: "the possibilities for epistemic friction and resistance are qualified and constrained for the sake, not of consensus and unification, but of coordination and cooperation" (283). This pragmatic understanding of pluralism is then radicalized by relying on a foucaultian conception of power to introduce a conception of "guerrilla pluralism" in which epistemic friction is now seen merely as a form of resistance against oppression. Friction is sought for its own sake. The goal is not to increase knowledge but resistance to power. Guerrilla pluralism does not seek to resolve conflicts but to energize them. Medina goes at great length in describing and comparing these competing views of pluralism, proposing in the end a combination of both which praises Foucault's disruptive force and James' creative potential. In conclusion, it is by relying on a cultivation of epistemic virtues, by denouncing so far still unrecognized forms of culpable ignorance and by fostering new resistant imaginaries that Medina proposes a normative account of how social oppression can be contrasted and reduced.

All in all, José Medina has written an original book which masterfully combines continental and American traditions and which addresses important topics in contemporary social and political philosophy, showing why we should pay more attention to the epistemic dimension of our everyday interactions. In this way, the volume offers a new and fresh interpretation of the foucauldian adage that "knowledge is power," one in which the creative and constraining forces that shape our everyday lives are brought into the focus of the shared responsibilities on which social life is built.

\section{AUTHORS}

\section{ROBERTO FREGA}

CEMS-IMM (EHESS/CNRS)

fregarob[at]gmail.com 